\title{
MANAJEMEN PARTISIPATIF DALAM PENGEMBANGAN BUDAYA RELIGIUS PESERTA DIDIK
}

\author{
Iwan Sopwandin ${ }^{1}$ Irawati Dewi ${ }^{* 2}$ Muhibbin Syah ${ }^{* 3}$ \\ ${ }^{1}$ Iwansopwandin8@gmail.com²Irawatidewi62@gmail.com³ Muhibbin.syah@uinsgd.ac.id \\ *Pascasarjana UIN Sunan Gunung Djati Bandung
}

\begin{abstract}
This study aims to determine the process of participatory management in the development of religious culture in Madrasah Ibtidaiyah Negeri (MIN) 2 Bandung City. This research uses descriptive qualitative method. The type of data collected in this study is qualitative data. The type of data collected in this study is qualitative data. Data collection is done by: a) observation, $b$ ) interview, and c) documentation. The results of this study indicate that: 1) The religious culture development program at MIN 2 Bandung, which is the first and most consistent priority, consists of six programs, namely: a) $5 S$ Culture (Smiles, Greetings, Greetings, Polite and Courteous), b) Pray when starting and ending learning, c) Dhuha Prayer, d) Dhuhr Prayer in congregation, e) Tilawah and Tahfidz. Al-Qur'an Before learning, f) Infaq every Friday; 2) The implementation or participatory management process in the development of religious culture in MIN 2 Bandung City is indicated by the existence of: a) The existence of participatory leadership, b) The implementation of participatory management indicators, $c$ ) The existence of a decision making model, d) The visible implementation of participatory management, e) The existence of participatory management delegation, $f$ ) Implementation of delegation procedures, $g$ ) Self management team.

Keywords: Participatory Management, Religious Culture
\end{abstract}

\begin{abstract}
Abstrak
Penelitian ini bertujuan mengetahui proses manajemen partisipatif dalam pengembangan budaya religius di Madrasah Ibtidaiyah Negeri (MIN) 2 Kota Bandung. Penelitian ini menggunakan metode kualitatif dekriptif. Jenis data yang dikumpulkan dalam penelitian ini adalah data kualitatif. Pengumpulan data dilakukan dengan cara: a) observasi, b) wawancara, dan c) dokumentasi. Hasil penelitian ini menunjukan bahwa: 1) Program pengembangan budaya religius di MIN 2 Kota Bandung yang menjadi prioritas utama dan konsisten dilaksanakan terdiri atas enam program, yaitu: a) Budaya 5S (Senyum, Salam, Sapa, Sopan, dan santun), b) Berdoa ketika mengawali dan mengakhiri pembelajaran, c) Shalat Dhuha, d) Shalat Dzuhur berjama'ah, e) Tilawah dan Tahfidz Al-Qur'an Sebelum belajar, f) Infaq setiap hari jum'at; 2) Penerapan atau proses manajemen partisipatif dalam pengembangan budaya religius di MIN 2 Kota Bandung ditunjukan dengan adanya: a) Adanya kepemimpinan partisipatid, b) Dilaksanakannya indikator manajemen partisipatif, c) Adanya model pengambilan keputusan, d) Terlihatnya implementasi manajemen partisipatif, e) Adanya pendelegasian, f) Dilaksanakannya tata cara pendelegasian, g) Self management team.
\end{abstract}

Kata kunci:Manajemen Partisipatif, Budaya Religius 


\section{PENDAHULUAN}

Pendidikan merupakan usaha sadar dan terencana untuk mewujudkan suasana belajar dan proses pembelajaran agar peserta didik secara aktif mengembangkan potensi dirinya untuk memiliki kekuatan spiritual keagamaan, pengendalian diri, kepribadian, kecerdasan, akhlak mulia, serta keterampilan yang diperlukan dirinya, masyarakat, bangsa dan Negara.(Nasional, UU No 20 tahun 2003 Tentang Sistem Pendidiikan, n.d.)Fungsi pendidikan nasional yaitu mengembangkan kemampuan dan membentuk watak serta peradaban bangsa yang bermartabat dalam rangka mencerdaskan kehidupan bangsa yang bertujuan untuk mengembangkan potensi peserta didik agar menjadi manusia yang beriman dan bertakwa kepada Tuhan Yang Maha Esa, yang didalamnya mencakupberakhlak mulia, sehat, berilmu, cakap, kreatif, mandiri, dan menjadi warga negara yang demokratis serta bertanggung jawab(Redaksi, 2013).

Mewujudkan peserta didik yang beriman dan bertakwa kepada Tuhan Yang Maha Esa (Allah SWT) dibutuhkan lingkungan yang mendukung serta kondusif untuk melaksanakan ajaran agamanya tersebut, selain didalam keluarga masing-masing dan masyarakat, sekolah juga berupaya mendukung hal tersebut melalui program pengembangan budaya religius.Budaya religius di sekolah merupakan upaya yang dilakukan untuk mewujudkan prilaku dan budaya organisasi yang berlandaskan nilai-nilai keagamaan(Sahlan, 2010a).

Budaya religius merupakan salah satu metode pendidikan nilai yang komprehensif, baik di dalamnya terdapat inkulnasi nilai, pemberian teladan, dan penyiapan generasi muda agar mandiri dengan mengajarkan, dan memfasilitasi perbuatanperbuatan keputusan moral secara bertanggung jawab dan keterampilan hidup yang lain.(Zuchdi, 2008)

Keberhasilan program pengembangan budaya religius ini ditentukan oleh keterlibatan atau partisipasi dari seluruh warga sekolah, karena tidak mungkin hal tersebut akan berjalan jika hanya satu dua orang saja yang peduli, mendukung dan berpartisipasi didalamnya. Untuk meningkatkan hal tersebut maka salah satu upayanya yang dilakukan melalui proses manajemen partisipasi.

Manajemen partisipasi merupakan partisipasi karyawan dalam pengambilan keputusan secara demokratis, suasana yang dibuat oleh kepemimpinan yang permisif, memfasilitasi pengembangan internalisasi motivasi dan menjaganya untuk menaikkan tingkat produksi dan moral karyawan(Rubiati, 2016b). Dengan demikian, sangat jelas bila manajemen partisipatif dapat dilaksanakan untuk pengembangan budaya religius, karena dalam pengambilan keputusan melibatkan seluruh warga sekolah, implikasi dari kegiatan tersebut juga bertujuan untuk menaikan moral atau akhlak peserta didik.

Manajemen partisipatif digunakan sebagai strategi pengelolaan kelima program tersebut agar dapat terus terlaksana dan berkesinambungan setiap tahunnya. Program pengembangan budaya religius ini seiring berjalannya waktu selalu mengalami perubahan, hal tersebut disebabkan oleh situasi dan kondisi sekolah/madrasah pada saat itu.

Pihak yang terlibat dalam manajemen partisipatif dalam pengembangan budaya religius ini yaitu kepala madrasah, tenaga pendidikan dan kependidikan, komite, orangtua dan pihak lain yang berkaitan dengan program tersebut. Pihak tersebut terlibat dalam pengambilan keputusan, pelaksanaan, pengawasan dan evaluasi. Tingkat partisipasi yang dilaksanakan berbeda-beda mengikuti tugas dan fungsinya masing-masing, sehingga dengan begitu seluruh sumber daya akan berperan penting pada bagiannya masing-masing.

\section{KAJIAN PUSTAKA Manajemen Partisipatif}

Dalam Kamus Besar Bahasa Indonesia partisipasi adalah perihalturut berperan serta dalam suatu kegiatan, keikutsertaan, peran serta(Poerwadarminta, 2006).Syarifuddin menjelaskan bahwa partisipasi adalah sesuatu yang menunjuk kepada adanya keikutsertaan secara nyata dalam suatu kegiatan. Partisipasi masyarakat dalam kebijakan pendidikan adalah keikutsertaan masyarakat dalam memberikan gagasan, kritik membangun, dukungan dan pelaksanaan kebijaksanaan pendidikan. Berdasarkan pendapat di atas partisipasi yang dimaksud dalam penelitian ini adalah ikut serta dalam suatu kegiatan secara langsung dalam artian orang-orang yang adanya aksi dan reaksi. Implementasi sistem pendidikan yang sentralistik selama kurun waktu tiga puluh tahun ternyata membawa dampak jauhnya lembaga-lembaga pendidikan dari lingkungan masyarakat, dengan kata lain masyarakat kurang memiliki lembaga pendidikan. Hal ini menimbulkan persepsi bahwa penyelenggaraan pendidikan sepenuhnya menjaditanggung jawab sekolah atau pemerintah. Sehingga tidak mengherankanhubungan antara masyarakat dengan institusi pendidikan dan partisipasi masyarakat dalam pendidikan selama ini lebih banyak bersifat kewajiban untuk mendukung input (dana) bukan pada proses pendidikan (pengambilan keputusan, monitoring dan pengawasan). Akibatnya sekolah tidak mempunyai beban untuk mempertanggungjawabkan hasil pelaksanaan pendidikan kepada stakeholders.

Partisipasi baik di lingkungan sekolah maupun di luar lingkungan sekolah tidaklah terjadi secara otoinatis. Untuk itu perlu perjuangan dari pihak sekolah (kepada sekolah) karena masih banyak masyarakat yang belum memahami betul 
arti dan makna partisipasi. Dalam kenyataannya kita mengenal bentuk partisipasi masyarakat melalu BP3 (Badan Pmebantu Penyelenggaraan Pendidilan) ataupun dengan istilah lain Komite Sekolah ataupun Majelis Madrasah. Namun kegiatannya hanya berkisar pada soal dana dan pembangunan fisik semata. partisipasi dalam konsep MBS sangatlah ditekankan mulai dari perencanaan program,melaksanakan sebagian kegiatan program (dalam proses pembelajaran)sempai kepada pengambilan keputusan, untuk itu partisipasi ini haruslahbetulbetul dikuasai. Supriono memaparkan : Peran serta, juga merupakan bagian penting dalam pelaksanaan Manajemen Berbasis Sekolah, untuk upaya menggalang peran serta masyarakat bagi terlaksananya pendidikan perlu diusahakan, di samping terlaksananya aspek-aspek lain dalampenyelenggaraan MBS(Supriono. S. dan Achmad Sapari, 2001).Tampaknya partisipasi warga sekolah yang diharapakan adalah memusatkan penajaman pada kerjasama, baik kerjasama dalam satukomunitas dalam hal ini sekolah maupun kerjasama di luar sekolah dalam hal ini masyarakat. Kerjasama itu pun tidaklah bersifat satu arah namun haruslah dibungkus semangat interaktif baik di dalam lingkungan sekolah maupun di luar lingkungan sekolah. Kerjasama yang dimaksud haruslah timbal balik antara sekolah dengan masyarakat, begitu juga sebaliknyarriasyarakat dengan sekolah. Besar dan kecilnva partisipasi masyarakat terhadap kegiatankegiatan yang ada di sekolah sangat ditentukan oleh keyakinan top manager (Kepala sekolah) terhadap penting dan perlunya peranan masyarakat itu sendiri.

1. Macam-, bentuk, dimensi dan tingkat partisipatif

Bentuk-bentuk partisipasi menurut Effendi sebagaimana dikutip SitiIrene A.D. terdapat dua bentuk yaitu partisipasi vertikal dan partisipasihorisontal. Partisipasi vertikal adalah partisipasi dalam bentuk keterlibatandalam suatu program pihak lain yang mana partisipan berstatus sebagaibawahan, pengikut atau klien. Sedangkan partisipasi horisontal adalahbentuk partisipasi yang mana masyarakat mempunyai prakarsa, setiapanggota atau kelompok berpartisipasi antara satu terhadap yang lainnya(Dwiningrum, 2011).Pengelompokan partisipasi lainnya yaitu pendapat Basrowi bahwapartisipasi berdasarkan bentuknya terbagi dua macam yaitu partisipasi fisikdan partisipasi non fisik. Partisipasi fisik adalah partisipasi dalam bentukbarang seperti uang, gedung, buku, dan lainnya. Sedangkan partisipasi non fisik adalah partisipasi dalam bentuk keikutsertaan masyarakat dalam melalui ide dan gagasan untuk menentukan arah pendidikan(Dwiningrum, 2011).Partisipasi warga sekolah internal baik pendidik, tenaga kependidikanmaupun peserta didik dalam suatu kegiatan biasanya lebih cenderung bersifat vertikal dan horisontal. Partisipasi orang tua, komite sekolah atau stakeholder lainnya biasanya cenderung bersifat partisipasi fisik dan non fisik. Contohnya partisipasi orang tua dalam pengembangan program-program sekolah baik pada tataran penyampaian ide-ide, gagasan maupun pada peran serta dalam proses pembiayaan.

Dimensi partisipasi dapat ditinjau dari dua perspektif, yaitu dimensi siapa yang harus berpartisipasi dan dimensi bagaimana partisipasi tersebut berlangsung(Dwiningrum, 2011). Dimensi tentang siapa yang berpartisipasi maka seluruh warga sekolah atau the stakeholder society berkewajiban berpartisipasi terdiri atas peserta didik, orang tua, pendidik, kepala sekolah, dan pengelola sekolah. Tentu partisipasi masing-masing komponen tersebut di atas tidak sama porsi dan bentuknya. Dimensi bagaimana partisipasi berlangsung menurut Uphoff dan Cohen terdapat 7 hal meliputi: pertama, apakah inisiatif datang dari administrator ataukah dari masyarakat setempat?; kedua, apakah dorongan partisipasi sukarela ataukah paksaan?; ketiga, struktur; keempat, saluran partisipasi, apakah saluran partisipasi itu bersifat individu atau kolektif, dalam organisasi formal atau informal? Apakah partisipasi tersebut langsung ataukah melalui wakil?; kelima, durasi partisipasi; keenam ruang lingkup partisipasi, apakah sekali ataukah seluruhnya, sementara atau berlanjut dan meluas?, memperluas atau mempersempit aktivitas?; ketujuh, memberdayakan, memberdayakan keterlibatan masyarakat scara efektif dalam pengambilan keputusan dan pelaksanaan yang mengarah pada hasil tujuan?(Rubiati, 2016a). Di sekolah, kedua dimensi harus diperhatikan dengan baik. Dimensi siapa yang harus berpartisipasi dan dimensi bagaimana partisipasi tersebut berlangsung, harus direncanakan, dan dikemas mendasar pada peraturan, orientasi program, dan kesepakatan para partisipan. Hal dimaksudkan supaya terdapat akuntabilitas manajemen partisipatif, sejak tahap perencanaan hingga tahap pengevaluasian program. Perencanaan dan pengemasan dimensi partisipasi warga sekolah merupakan hal yang penting, karena sebuah program yang melibatkan partisipasi banyak pihak maka kemampuan mengelola kepercayaan semua pihak harus diutamakan. Kepercayaan yang baik dari seluruh partisipan terhadap suatu program sekolah dapat mendorong adanya partisipasi spontan lainnya yang akan menumbuhkan kreativitas dan meningkatkan produktivitas serta sekaligus meningkatkan tanggung jawab terhadap pelaksanaan dan hasil program(Tilaar, 2011).

Dengan asumsi bahwa partisipasi dapat menggerakkan dinamikamasyarakat sekolah, berikut Peneliti menampilkan 7 tabel tangga 
partisipasi menurut Peter Oakley, yaitu:(Dwiningrum, 2011)

Tabel 1. Tingkatan Partisipasi menurut Peter Oakley

\begin{tabular}{|c|c|}
\hline $\begin{array}{c}\text { Tingkat } \\
\text { Partisipasi }\end{array}$ & Deskripsi \\
\hline Manipulation & $\begin{array}{l}\text { Tingkat paling rendah } \\
\text { mendekati situasi tidak ada } \\
\text { partisipasi, } \\
\text { cenderung berbentuk } \\
\text { indoktrinasi. }\end{array}$ \\
\hline $\begin{array}{l}\text { Consultation } \\
\text { Stakeholder }\end{array}$ & $\begin{array}{l}\text { mempunyai peluang untuk } \\
\text { memberikan saranakan } \\
\text { digunakan seperti yang } \\
\text { mereka harapkan. }\end{array}$ \\
\hline $\begin{array}{l}\text { Consensus } \\
\text { Building }\end{array}$ & $\begin{array}{l}\text { Stakeholder berinteraksi } \\
\text { untuk saling memahami } \\
\text { dan dalamposisi saling } \\
\text { bernegosiasi, toleransi } \\
\text { dengan seluruh anggota } \\
\text { kelompok. Kelemahan } \\
\text { yang sering terjadi adalah } \\
\text { individuindividu dan } \\
\text { kelompok masih cenderung } \\
\text { diam atau setuju bersifat } \\
\text { pasif. }\end{array}$ \\
\hline $\begin{array}{l}\text { Decition } \\
\text { making }\end{array}$ & $\begin{array}{lr}\text { Konsensus } & \text { terjadi } \\
\text { didasarkan } & \text { keputusan } \\
\text { kolektif danbersumber pada } \\
\text { rasa tanggung jawab untuk } \\
\text { menghasilkan } & \text { sesuatu. } \\
\text { Negosiasi pada tahap ini } \\
\text { mencerminkan derajat } \\
\text { perbedaan yang terjadi } \\
\text { dalam individu dan } \\
\text { kelompok. }\end{array}$ \\
\hline Risk taking & $\begin{array}{l}\text { Proses yang berlangsung } \\
\text { dan berkembang tidak } \\
\text { hanyasekedar } \\
\text { menghasilkan keputusan, } \\
\text { tetapi memikirkan akibat } \\
\text { dari hasil yang menyangkut } \\
\text { keuntungan, hambatan, dan } \\
\text { implikasi. Pada tahap ini } \\
\text { semua orang memikirkan } \\
\text { resiko yang diharapkan dari } \\
\text { hasil keputusan. Karenanya } \\
\text { akuntabilitas merupakan } \\
\text { basis yang penting. }\end{array}$ \\
\hline Partnership & $\begin{array}{l}\text { Memerlukan kerja secara } \\
\text { equal menuju hasil yang } \\
\text { mutual.Equal tidak hanya } \\
\text { sekedar dalam bentuk } \\
\text { struktur dan fungsitetapi } \\
\text { equal dalam tanggung } \\
\text { jawab. }\end{array}$ \\
\hline Self managmen & $\begin{array}{lr}\text { Puncak } & \text { partisipasi } \\
\text { masyarakat. } & \text { Stakeholder } \\
\text { berinteraksidalam } & \text { proses }\end{array}$ \\
\hline
\end{tabular}

\begin{tabular}{|l|lr|}
\hline & $\begin{array}{l}\text { saling belajar } \\
\text { process) }\end{array}$ & (learning \\
mengoptimalkan hasil dan \\
hal-hal yang menjadi \\
perhatian.
\end{tabular}

Sumber: (Effendi., n.d.)

\section{Indikator manajemen partisipatif}

Pelaksanaan manajemen partisipatif yang baik harus memenuhikriteria-kriteria tertentu. Menurut Yukl, terdapat 7 indikator manajemenpartisipatif yang baik(Rubiati, 2016a). Ketujuh Indikator manajemen partisipatif tersebutadalah: Pertama, dilaksanakannya sifat kepemimpinan partisipatif; Kedua,dilaksanakannya proses kepemimpinan partisipatif; ketiga, dilaksanakannyaindikator manajemen partisipatif; keempat, adanya model pengambilan keputusan; kelima, terlihatnya aplikasi manajemen partisipatif; keenam, adanya proses pendelegasian; ketujuh, dilaksanakannya tata cara pendelegasian.

\section{Pengembangan Budaya Religius}

Budaya religius menurut Muhaimin adalah cara berfikir dan carabertindak yang didasarkan atas nilai-nilai religius (keberagamaan). Religius menurut Islam adalah menjalankan ajaran agama secara menyeluruh (kaffah)(Muhaimin, 2001).Sedangkan Asmaun Sahlan mendefinisikan budaya religious sebagai upaya terwujudnya nilainilai ajaran agama sebagai tradisi dalam berperilaku dan budaya organisasi yang diikuti oleh seluruh warga di sekolah tersebut(Sahlan, 2010b).Dengan mendasar pada kedua pendapat tersebut di atas, maka dapat dikatakan bahwa, budaya religius sekolah adalah terwujudnya nilainilai ajaran agama secara menyeluruh sebagai tradisi dalam berperilaku dan budaya organisasi yang diikuti oleh seluruh warga sekolah. Pentingnya mewujudkan nilai-nilai agama islam secara menyeluruh sebagai dasar dalam berfikir dan bertindak oleh seluruh warga sekolah, ini sesuai dengan firman Allah SWT dalam QS. AlBaqarah ayat 208: (Rubiati, 2016a), Hai orangorang yang beriman, masuklah kamu ke dalam Islam secara keseluruhan dan janganlah kamu turuti langkah-langkah setan. Sesungguhnya setan itu musuh yangnyata bagimu ${ }^{e}$.Budaya religius di sekolah diperlukan sebagai bagian dari upaya pengembangan pendidikan sesuai dengan pengertian pendidikan itu sendiri, dirumuskan dalam Pasal 1 Undang-Undang-undang bahwa Pendidikan adalah usaha sadar dan terencana untuk mewujudkan suasana belajar dan proses pembelajaran agar peserta didik secara aktif mengembangkan potensi dirinya untuk memiliki kekuatan spiritual keagamaan, pengendalian diri, kepribadian, kecerdasan, akhlak mulia, serta ketrampilan, yang diperlukan dirinya, masyarakat, 
berbangsa dan bernegara(Perundangan Tentang Kurikulum Sistem Pendidikan Nasional 2013, n.d.).

\section{METODE PENELITIAN}

Metodologi dan prosedur penelitian yang dilakukan peneliti meliputi: (1) Metode penelitian, (2) Jenis dan sumber penelitian, (3) Tempat penelitian, (4) Teknik pengumpulan data penelitian. Secara rinci keempat tahapan tersebut diuraikan sebagai berikut:

\section{Metode penelitian}

Penelitian ini menggunakan metode kualitatif dekriptif. Penelitian ini memberikan gambaran dan mendeskripsikan secara objektif, faktual dan mendalam mengenai manajemen partisipatif dalam pengembangan budaya religius peserta didik di MIN 2 Kota Bandung.

\section{Jenis dan Sumber penelitian}

a.Jenis data penelitian

Jenis data yang dikumpulkan dalam penelitian ini adalah data kualitatif. Data kualitatif adalah kata-kata dan tindakan selebihnya adalah data tambahan seperti dokumen dan lain-lain mengenai program-program pengembangan budaya religius peserta didik di MIN 2 Kota Bandung(Moleong, 2011).

b. Sumber data penelitian

Data ini bersumber dariorang yang diamati, diwawancarai, dan dicatat melalui catatan tertulis atau melalui rekaman video atau pengambilan foto. Untuk mendapatkan data tersebut penulis mewawancarai Kepala MIN 2 Kota Bandung, tenaga pendidik dan kependidikan, komite dan orangtua.

\section{Tempat dan waktu penelitian}

Penelitian ini dilakukan di MIN 2 Kota Bandung, Jl. Cipamokolan No 50, Dewati, Kecamatan Rancasari, Kota Bandung, Provinsi Jawa Barat.

\section{Teknik pengumpulan data penelitian}

Teknik yang dipakai dalam pengumpulan data yaitu: a) teknik observasi, b) teknik wawancara, dan c) teknik dokumentasi.

a. Teknik Observasi

Teknik observasi merupakan aktivitas peneliti yang langsung turun ke lapangan untuk mengamati perilaku dan aktivitas individu-individu di lokasi penelitian(Moleong, 2011).

Teknik ini bertujuan untuk mengumpulkan data-data: letak geografis, sarana prasarana, letak gedung dan lingkungan, dan Visi Misi MIN 2 Kota Bandung. Selama berada di lokasi, penulis akan berusaha menjadi pengamat yang secara terbuka dan diketahui oleh umum agar memudahkan dalam penarikan informasi.

b. Teknik Wawancara
Teknik wawancara adalah teknik pengumpulan data apabila peneliti ingin melakukan studi pendahuluan untuk menemukan permasalahan yang harus diteliti, tetapi juga apabila peneliti ingin mengetahui hal-hal dari responden yang lebih mendalam(Moleong, 2011).

Dalam penelitian ini wawancara digunakan untuk mengetahui secara lebih mendalam tentang program-program pengembangan budaya religius di MIN 2 Kota Bandung, keterkaitan Visi Misi dengan program dengan pengembangan budaya religius, serta penerapan manajemen partisipatif dalam pengembangan budaya religius peserta didik..

c. Teknik Dokumentasi dan Teknik Penyalinan Dokumen

Teknik ini bertujuan untuk mendapatkan data-data tertulis yang dilakukan dengan cara penelusuran, dokumen, buku yang berkaitan dengan manajemen partisipatif falam pengembangan budaya religius peserta didik MIN 2 Kota Bandung.

\section{HASIL DAN PEMBAHASAN}

Program pengembangan budaya religius peserta didik MIN 2 Kota Bandung

Program pengembangan budaya religius bagi peserta didik di MIN 2 Kota Bandung terdiri dari banyak program baik itu yang rutin maupun yang sifatnya insidental, yang menjadi prioritas utama dan konsisten dilaksanakan terdiri atas enam program, yaitu: 1) Budaya 5S (Senyum, Salam, Sapa,Sopan, dan santun), 2) Berdoa ketika mengawali dan mengakhiri pembelajaran, 3) Shalat Dhuha, 4) Shalat Dzuhur berjama'ah, 5) Tilawah dan Tahfidz Al-Qur'an Sebelum belajar, 6) Infaq setiap hari jum'at(HWdKM, 2019).

\section{Budaya 5S (Senyum, Salam, Sapa, Sopan, dan Santun)}

Konsep ini merupakan pengembangan budaya religius yang diorientasikan pada pembiasaan akhlak mulia, kepada siapa saja. Konsep ini dilaksanakan setiap hari, dan selalu disampaikan kepada peserta didik, ketika ada momen-momen upacara ataupun didalam kelas oleh guru kelasnya masing, hal ini dilaksanakan agar peserta didik terus teringatkan, karena tidak menutup kemungkinan peserta didik lupa dengan hal tersebut. Hal tersebut juga bila sering diingatkan, secara tidak sadar, nasihat guru tersebut akan masuk pada alam bawah sadar peserta didik. Selanjutnya, pada konsep ini guru bukan hanya menyampaikannya lewat lisan, tetapi juga mereka memberikan contoh langsung, seperti pada saat sambut anak, guru menyapa terlebih dahulu peserta didik yang datang sambil tersenyum ramah. 


\section{Berdoa ketika mengawali dan Mengakhiri kegiatan pembelajaran}

Budaya berdo'a sejatinya bukan pengembangan budaya religius baru, melainkan ini sudah lama diterapkan di MIN 2 Kota Bandung. Pada saat berdo'a dikelas, peserta didik berdo'a bersama-sama dengan dikomandoi oleh ketua kelas. Tujuan berdo'a ini tentunya berharap peserta didik diberikan pemahaman atas apa yang akan dan telah dipelajarinya serta berharap keberkahan dari Allah SWT.

\section{Shalat Dhuha}

Shalat Dhuha merupakan praktik ibadah shalat yang sifatnya sunnah. Peserta didik diajarkan bukan hanya ibadah yang wajib saja tetapi sejak dini telah dididik untuk melaksanakan ibadahibadah yang sunnah. Shalat dhuha dilaksanakan setiap hari.tetapi karena kapasitas masjid sekolah yang tidak terlalu besar dan tidak cukup untuk menampung seluruh peserta didik, maka setiap hari yang shalat dhuha berbeda-beda, jadi setiap kelas bergantian, tetapi khusus hari jum'at semua kelas shalat dhuha. Lokasi yang digunakan pada hari jum'at yaitu masjid dan halaman sekolah.

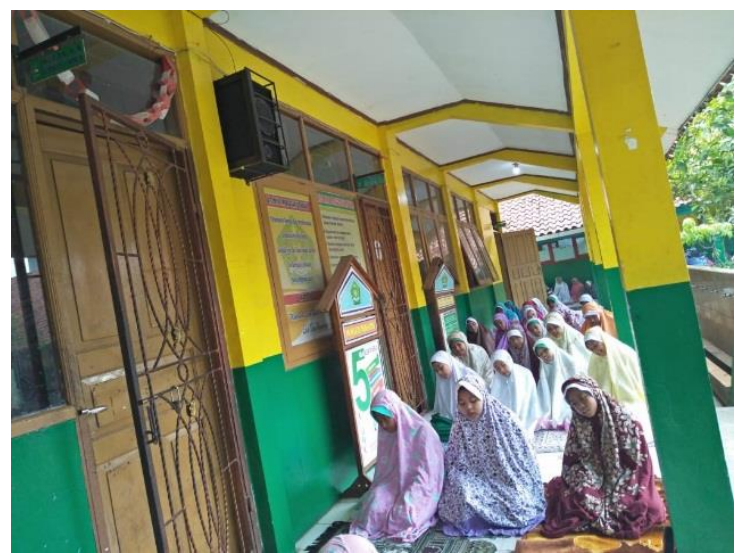

Gambar 1. Kegiatan Shalat Dhuha di depan kelas

\section{Shalat Dzuhur Berjama'ah}

Program shalat Dzuhur berjama'ah merupakan pengembangan budaya religius yang berorientasi pada hubungan ibadah manusia dengan Allah SWT. Program ini menyangkut pembiasaan peserta didik agar mereka semakin meningkatkan keimanan dan ketaqwaan kepada Allah SWT. Bukan hanya sekedar melaksanakan kewajiban shalat saja, tetapi juga melaksanakan keutamaan shalatnya yaitu berjama'ah. Hal tersebut juga bias diimplikasikan bahwa ketika kita berjalan bersamasama hasil yang akan dicapai akan lebih baik dibanding berjalan sendiri.Lokasi shalat dzuhur yaitu mesjid. Untuk mengantisipasi masjid yang minim, shalat dzuhur berjama'ah dilaksanakan dibagi beberapa kloter, sehingga kegiatan tersebut tetap berjalan dengan lancar.

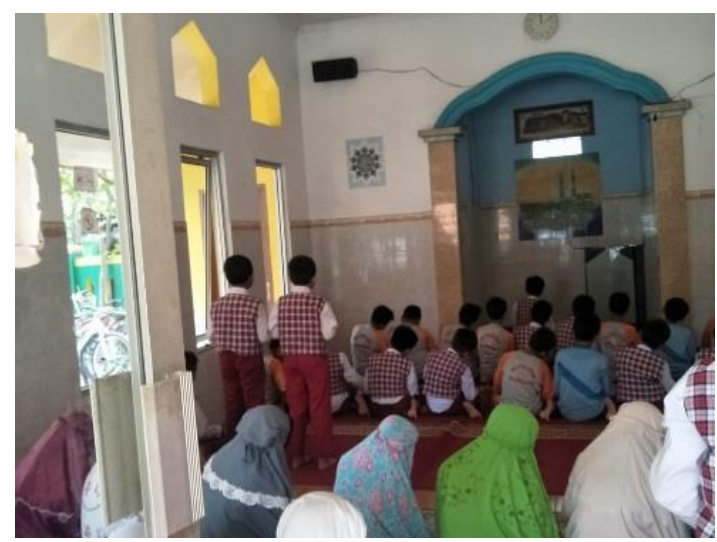

Gambar 2. Kegiatan Shalat Dzuhur Berjama'ah

\section{Tilawah dan Tahfidz Al-Qur'an Sebelum belajar}

Program ini adalah pengembangan budaya religius yang berorientasi pada keta'atan peserta didik, dengan senantiasa membaca atau menghapal Al-Qur'an, maka peserta didik secara sadar atau tidak sadar telah mengamalkan dan menjaga ajaran agama islam. Program ini setiap hari dilaksanakan, hanya saja setiap guru berbeda-beda penerapannya, ada yang Tilawah saja ada juga yang Tahfidz Qur'an, tergantung pada target yang ingin dicapai oleh guru tersebut.

\section{Infaq setiap hari jum'at}

Program ini mengajarkan kepada peserta didik agar berusaha menyisihkan sebagian hartanya untuk kebaikan dan berbagi untuk sesama. Program ini dikoordinir oleh sekolah melalui wali kelas. Setiap pulang sekolah, hasil dari infaq tersebut di serahkan kepada sekolah untuk disalurkan kepada yang berhak.Dana yang terkumpul dipergunakan untuk kebutuhan sekolah, contohnya kebersihan dan untuk menjenguk orang sakit.

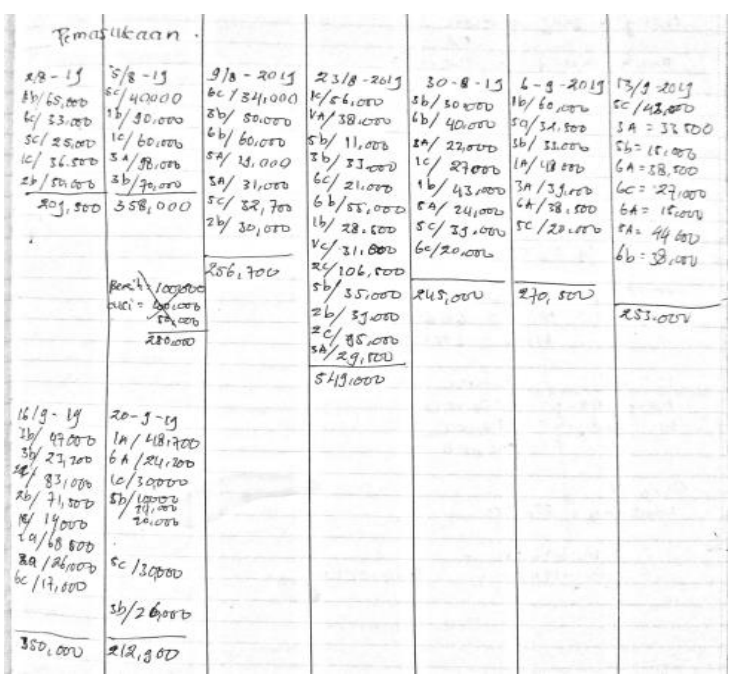

Gambar 3. Pemasukan Infaq Semester 1 Tahun Pelajaran 2019-2020 


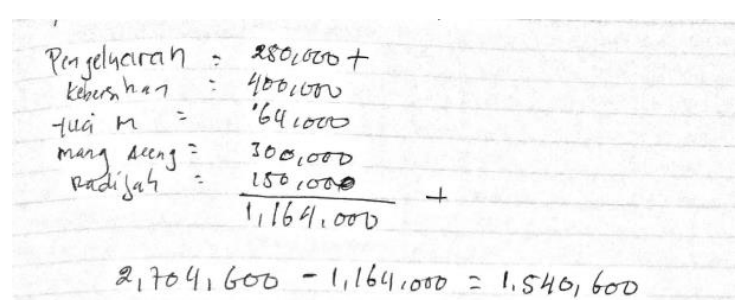

Gambar 4. Catatan Pengeluaran Infaq Semester 1 Tahun Pelajaran 2019-2020

Penerapan manajemen partisipatif warga sekolah dalam pengembangan budaya religius peserta didik

Manajemen partisipatif di MIN 2 Kota Bandung sudah diterapkan dengan baik, khususnya pada pengembangan budaya religius peserta didik, diantara data yang menjadikan dasar tersebut yaitu:

\section{Adanya sifat kepemimpinan partisipatif}

Kepemimpinan yang partisipatif terlihat pada prosedur pengelolaan program pengembangan budaya religius mulai dari tahapan perencanaan, pelaksanaan, pengawasan dan evaluasi sudah melibatkan banyak pihak untuk ikut andil pada proses tersebut. madrasah mempunyai wewenang untuk menampung serta menindaklanjuti ide dan gagasan yang mengarah pada kemajuan yang berorientasi keagamaan disekolah. sehingga pada implementasinya ada program-program yang menjadi tanggung jawab bersama.

\section{Dilaksanakannya indikator manajemen partisipatif \\ Tujuh indikator manajemen partisipatif} dilaksanakan dalam program pengembangan budaya religius peserta didik MIN 2 Kota Bandung. hal ini meliputi adanya kepemimpinan yang partisipatid disemua level disetiap program keagamaan, keragaman sumber gagasan program keagamaan,pengambilan keputusan yang prosedural, pendelegasian keputusan program keagamaan kepada pihak tertentu secara proporsional dan profesional, serta adanya kontrol/pengawasan dan evaluasi yang transparan dan akuntabel.

\section{Adanya model pengambilan keputusan}

Model pengambilan keputusan contohnya tampak pada penyampaian ide yang disalurkan dan dibahas dalam rapat dengan dasar program , pertimbangan dan korelasinya dengan visi misi madrasah. model pengambilan keputusan di MIN 2 KOta Bandung salah satunya pada hal ide atau gagasan yang disampaikan kepada kepala madarsah lalu dibahas dalam rapat perencanaan program dengan mempertimbangkan segal aspek, baik itu SDM ataupun saran pendukungnya.

Contohnya pada program shalat dhuha dengan segala pertimbangan, sehingga setiap hari tidak seluruh kelas seluruhnya mengerjakan, tetapi dibagi-bagi, da nada momen shalat bersama yaitu pada hari jum'at, keputusan tersebut diambil berdasarkan pertimbangan sarana prasarana yang tidak memadai.

\section{Terlihatnya implementasi manajemen partisipatif \\ Implementasi manajemen partisipatif di} MIN 2 Kota Bandung terlihat pada proses perencanaan, pelaksanaan, pengawasan dan evaluasi yang melibatkan seluruh warga sekolah. Ide yang muncul dari siapapun disampaikan kepada kepala sekolah dan dibahas dalam rapat, jika disepakati maka diambil keputusan dan dijadikan program. Kepala madrasah tidak memaksakan program yang tidak disepakati.

\section{Adanya pendelegasian}

Contohnya, shalat dhuha yang dilaksanakan setiap hari, setelah diambil keputusan, maka kepala madrasah mendelegasikan pelaksanaan dan pengawasannya kepada masingmasing wali kelas agar dilaksanakan oleh warga sekolah, dalam hal ini peserta didik.

\section{Dilaksanakannya tata cara pendelegasian}

Tata cara pendelegasian sebagai bagian dari manajemen partisipatif dalam pengembangan budaya religius di MIN 2 Kota Bandung dapat dipahami dari paparan salah satu guru mata pelajaran seni budaya dan prakarya, Irawati Dewi. Contohnya pendelegasian pada pelaksanaan shalat dhuha, wali kelas diberikan pemahaman terlebih dahulu mengenai mekanisme shalat dhuha tersebut, sehingga wali kelas mengetahui tata caranya.Pendelegasian diatas sesuai dengan rumusan yang dikemukakan oleh Syahrizal Abbas, bahwa pendelegasian efektif adalah pendelgasian yang memenuhi beberapa kriteria, yaitu: pertama, adanya ditermine atau penentuan secara jelas karakter tugas yang akan dlimpahkan kepada bawahan; kedua, evaluasi terhadap tiga unsur yaitu komitmen, kompeten dan komplit, artinya pendelegasian ditujukan kepada bawahan yang memenuhi keteguhan hati, kemampuan dan kesempatan; ketiga, asses, yaitu mengetahui secra riil tentang dukungan yang dibutuhkan oleh bawahan dalam rangka menajlankan tugas; keempat, leave yaitu pemberian kebebasan dan keleluasaan kepada bawahan untuk melaksanakan tugas(Syahrizal, 2009).

\section{Self management team}

Self management team yaitu kemapuan team atau warga sekolah yang ditunjuk, untuk mengelola diri mereka sendiri bersama kelompoknya dalam melaksanakan tugas yang diberikan sehingga kinerja mereka berjalan efektif 
untuk mencapai tujuan program keagamaan tersebut.

Respon warga sekolah terhadap manajemen partisipatif dalam pengembangan budaya religious peserta didik MIN 2 Kota Bandung

Berdasarkan hasil penelitian ini, maka dapat diperoleh gambaran bahwa respon partisipasi warga sekolah menunjukan persepsi, sikap dan tindakan yang positif terhadap pengembangan budaya religius peserta didik di MIN 2 Kota Bandung. Hal ini dibuktikan dengan adanya partisipasi pendidik dan tenaga kependidikan, peserta didik juga dalam realisasi program keagamaan sangat baik. peserta didik menerapkan $5 \mathrm{~S}$, selalu mengikuti shalat dhuha sesuai jadwalnya, shalat dzuhur berjama'ah dan tepat waktu, selalu berdoa sebelum dan setelah belajar, membaca dan menghapal Al-Qur'an mengikuti intruksi guru dan mulai membiasakan menyisihkan sebagian hartanya melalui infaq hari jum'at.

Orangtua juga memberikan respon yang sangat baik, mereka bersyukur dengan adanya manajemen partisipatif dalam pengembangan budaya religius tersebut berdampak pada kontinuitas berjalannya program religius tersebut, dan secara tidak langsung menanamkan nilai-nilai atau akhlak baik kepada putra-putrinya(HWdOPD, n.d.).

\section{KESIMPULAN DAN SARAN}

Program pengembangan religius berbentuk program yang bertujuan mewujudkan nilai-nilai agama sebagai dasar pola pikir dan perilaku dan budaya organisasi dalam rangka mencapai visi misi madrasah. program tersebut dilaksanakan secara komprehensif meliputi inklusi, keteladanan dan memfasilitasi generasi mandiri.

Penerapan manajemen partisipatif dalam pengembangan budaya religius beradasarkan indikatornya telah berjalan dengan baik, hal tersebut dibuktikan dengan pemenuhan indikator manajemen partisipatif tersebut. Respon dari warga sekolahpun sangat baik atas adanya manajemen tersebut, sehingga semuanya dapat merasakan manfaatnya.

Manajemen partisipatif pada MIN 2 Kota Bandung menunjukan dampak positif bagi semua pihak, sehingga hal tersebut bias diterapkan juga pada sekolah atau madrasah lainnya, dengan tujuan meningkatkan kualitas sekolah atau madrasah tersebut.

\section{DAFTAR PUSTAKA}

Dwiningrum, S. I. A. (2011). Desentralisasi dan Partisipasi Masyarakat dalam Pendidikan. Yogyakarta: Pustaka Pelajar.

Effendi., T. N. (n.d.). Konsep Partisipasi Menuju Pemberdayaan Masyarakat.
HWdGKE. (2019). Hasil wawancara dengan Guru Kelas Empat.

HWdKM. (2019). Hasil wawancara dengan Kepala Madrasah.

HWdOPD. (n.d.). Hasil wawancara dengan orangtua peserta didik.

Moleong, L. (2011). Metodologi Penelitian Kualitatif. Bandung: PT Remaja Rosda Karya.

Muhaimin. (2001). Paradigma Pendidikan Islam. Bandung: Remaja Rosdakarya.

Nasional, UU No 20 tahun 2003 Tentang Sistem Pendidiikan. (n.d.).

Perundangan Tentang Kurikulum Sistem Pendidikan Nasional 2013.

Poerwadarminta. (2006). Kamus Besar Bahasa Indonesia. jakarta: balai pustaka.

Redaksi, T. (2013). Perundangan Tentang Kurikulum Sistem Pendidikan Nasional 2013. Yogyakarta: Pustaka Yustisia.

Rubiati. (2016a). Manajemen Partisipatif warga sekolah dalam pengembangan budaya religius. Muslim Heritage, 1(2).

Rubiati. (2016b). Motivation and Morale in industry. STAIN Ponorogo, Ponorogo.

Sahlan, A. (2010a). Mewujudkan Budaya Religius di Sekolah: Upaya Mengembangkan PAI dari Teori ke Aksi. Malang: UIN Maliki Pres.

Sahlan, A. (2010b). Mewujudkan Budaya Religius di Sekolah: Upaya Mengembangkan PAI dari Teori ke Aksi.

Supriono. S. dan Achmad Sapari. (2001). Manajemen Berbasis Sekolah. (Jawa Timur: SIC.

Syahrizal, A. (2009). Manajemen perguruan tinggi. Jakarta: Kencana.

Tilaar, H. A. . (2011). Managemen Pendidikan Nasional. Bandung: Remaja Rosdakarya.

Zuchdi, D. (2008). Humanisasi Pendidikan: Menemukan kembali pendidikan yang manusiawi. Jakarta: Bumi Aksara. 